\title{
Illicit drugs, infectious disease and public health: A historical perspective
}

\author{
Virginia Berridge BA PhD FRHistS HonMFPH, Shawna Bourne BASc MHS CPHI(C)
}

\begin{abstract}
V Berridge, S Bourne. Illicit drugs, infectious disease and public health: A historical perspective. Can J Infect Dis Med Microbiol 2005;16(3):193-196.

The present report outlines a presentation by Professor Virginia Berridge at the Second Stanier Lecture held in Halifax, Nova Scotia, on November 5, 2002. The relationship among public health concepts, illicit drug use prevention and policy, and infection control strategies in England and other locations is paralleled over the course of two centuries. This historical journey analyzes changes in public health and demonstrates how history and public health have intersected at various times to result in the public health approaches used today.
\end{abstract}

Key Words: History; HIVIAIDS; Illicit drugs; Infectious disease; Public health

\section{Les drogues illicites, les maladies infectieuses et la santé publique : Une perspective his- torique}

\begin{abstract}
Le présent compte rendu résume une présentation du professeur Virginia Berridge donnée à la deuxième conférence Stanier tenue à Halifax, en Nouvelle-Écosse, le 5 novembre 2002. Le lien entre les concepts de santé publique, la prévention et les politiques en matière de consommation de drogues ainsi que les stratégies de contrôle des infections en Angleterre et dans d'autres régions est mis en parallèle sur une période de deux siècles. Cette expédition historique permet d'analyser les modifications en santé publique et de démontrer les interactions entre l'histoire et la santé publique à diverses époques pour parvenir aux démarches de santé publique utilisées aujourd'hui.
\end{abstract}

The present paper deals with two themes: changes in the nature and ideology of public health since the 18th century, and intersections between the history of the United Kingdom drug policy and these public health concepts.

\section{THE EARLY 19TH CENTURY}

The 18th century saw a local approach to the development of public health in the United Kingdom. However, by the 19th century, a new approach was developed in response to epidemics in newly developing towns and cities. Alexis de Tocqueville (1) describes the state of Manchester, England in 1835, and highlights two factors: the wealth emanating from this setting, and the poor health of the workers on which this wealth was built:

"From this foul drain the greatest stream of human industry flows out to fertilize the whole world. From this filthy sewer pure gold flows. Here humanity attains its most complete development and its most brutish; here civilization works its miracles and civilized man is turned almost into a savage" (1).

The two key factors affecting life expectancy in this period were location (whether one lived in a town) and social class. Edwin Chadwick's report (2) on the sanitary condition of the labouring population in 1842 cited many concerns similar to de Tocqueville, and led to the development of England's shortlived Central Board of Health (1848-1854).
In 1872, England enacted a Public Health Act that also functioned as a housing act; this was a typical strategy at the time, in which central legislation was developed to enable and empower local public health intervention. The Public Health Act had a very broad mandate that included all aspects of housing and the environment. It would be an oversimplification to argue that the environmental conditions of the time made such action inevitable; public health was more than a moral crusade and included fears of urban degeneration (that the urban industrial mass and urban poverty menaced the whole nation). Historically speaking, this was comparable to the general panic and fear mongering that occurred with the emergence of AIDS in the 1980s.

As time progressed, the workhouse became a device for controlling the large number of paupers. The New Poor Law promulgated in 1834 was closely allied to the ideas of public health; specifically, health, economy and social control were all inextricably entwined. Public health was thus underpinned by 'human capital' arguments focused on securing a functioning, working population, in addition to the moral perspective. Christopher Hamlin (3), an American historian of British public health, argues that the public health movement precluded wider social change; in Britain, public health acted as a form of control (3). In contrast, working class radicalism had wider aims in other countries. For example, in Prussia, Rudolf Virchow recognized that health promotion involved social radicalism, and revolutionary physicians participated in Prussia's 1848 insurgency.

Second Stanier Lecture (delivered November 5, 2002 in Halifax, Nova Scotia, by V Berridge of the London School of Hygiene and Tropical Medicine, London, United Kingdom). Reported and edited by S Bourne

Correspondence and reprints: Dr Virginia Berridge, Centre for History in Public Health, London School of Hygiene and Tropical Medicine,

Keppel Street, London WC1E 7HT, United Kingdom. E-mail virginia.berridge@lshtm.ac.uk

Received for publication September 26, 2004. Accepted October 21, 2004 


\section{LATE 19TH CENTURY GERM THEORY AND THE BACTERIOLOGICAL REVOLUTION}

British public health, unlike that in Prussia, had limited radicalism in the late 19th century. Some historians have argued that the nature of its mandate was further circumscribed by the arrival of germ theory. Germ theory gained popularity as scientists accepted the concept that infectious diseases arose from agents of disease or 'germs' passed from one individual to another. The work of scientists such as Ignaz Semmelweis and Louis Pasteur brought credence to germ theory and augmented the role of laboratory science and medicine. This newly formed emphasis on germs as a mode of disease transmission changed the focus of public health to individuals rather than environmental hygiene, although as Worboys has argued (4), the dissemination of the idea was more extenuated than once thought. Dorothy Porter (5) has pointed out that this interpretation carries with it a new form of environmentalism that stresses the individual in the environment. Thus, social behaviour, in addition to sanitarianism, became the new focus.

\section{THE EARLY 20TH CENTURY}

In a third stage in the redefinition of public health, the focus shifted from strict control and legislation to education and social hygiene under changing political goals. In the late 19th and early 20th centuries, the social behaviour of individuals was the focus of public health. Social behaviour was seen as either biologically determined or the result of inherited traits. The new science of eugenics was used to link demography and degeneration with the quality of the population. There were calls for compulsory sterilization to prevent hereditary defects such as severe alcoholism, congenital mental defects and disorders, and hereditary epilepsy. Parallels of this can be seen in the modern focus on genetic manipulation.

In controlling the quality of the population, individual intervention was seen as the key. Domestic hygiene habits were to be improved, and individual reform was to come through educating mothers either at home by health visitors or by instituting schools for mothers. Health advocates saw high infant mortality as the result of feckless mothering rather than the outcome of poverty and disadvantage. The goal was to secure national efficiency rather than a notion of positive health (6).

\section{WORLD WAR II AND THE ORIGINS OF THE "NEW PUBLIC HEALTH"}

Following World War II, there was a move toward a new perspective on public health. The 1944 White Paper published en route to the new National Health Service stated a new aim for health services (7):

"...divorce the case of health from questions of personal means and other factors irrelevant to it: to provide the service free of charge... and to encourage a new attitude to health - the easier obtaining of advice early, the promotion of good health rather than only the treatment of bad" (7).

Unfortunately, the National Health Service, like many health care systems both then and today, was intentionally structured for dealing with illness rather than functioning as a health or wellness service (8).
The 1950s and 1960s were a time of high-technology medicine. Epidemic infectious disease was viewed as a thing of the past, as 'magic bullets' were developed for tuberculosis and smallpox (smallpox was eventually eradicated). With the advent of potent vaccines and antibiotics, public health took a back seat in the development of the health care model.

A new public health emerged which had many faces in modern society. The first 'face' or version of new public health arose in the 1970s. In Canada, the Federal Minister of Health released the Lalonde Report in 1974 (9). This report, entitled "A New Perspective on the Health of Canadians", derived from the work of Thomas McKeown, Professor of Social Medicine at the University of Birmingham in England (10). The McKeown thesis was a sustained historical critique of "modern curative medicine" (10). McKeown argued that improved nutrition and better standards of living contributed more to decreased mortality rates than high-technology medical interventions. Other countries also produced documents supporting a broader focus and scope to health care. In 1976, the British government produced a document entitled, "Prevention and Health: Everybody's Business", epitomizing the focus on individual responsibility for health (11).

A second key change to public health in this period was the internationalization of the new public health. In 1977, the World Health Organization adopted "Health for all by the Year 2000" and the Healthy Cities movement began to spread across Europe (11).

A key initial issue in the modern public health campaign was smoking and lung cancer; a focus representative of the new style of public health (12). Air pollution and the environment, which had been matters of concern, were downgraded. Smoking and lung cancer was a new role for public health that promoted risk factor epidemiology in relation to a noninfectious disease. This was a new approach whereby a change in individual behaviour could affect the health of the population as a whole, thus improving general population health. The new agenda focused on individual responsibility, behavioural changes and fiscal policy through taxation and marketing techniques. The basis of these changes was the epidemiological concept of risk and the role of statistical association. Biological causation and laboratory confirmation of disease and causation became less important to public health (12).

\section{ILLICIT DRUGS AND PUBLIC HEALTH}

Illicit drug use offers an interesting parallel to the changes in public health, as seen in the language of public health since the 1960s. Drug use has had a great impact on the redefinition of public health in the late 20th century. HIV/AIDS and its mode of transmission brought the issue of epidemic disease to the forefront of public health, and at the same time brought illicit drug use out of the ghetto and into the mainstream. Drug policy questions arose where concepts and grounded values intersected.

From the late 19th century and up until the 1960s, the connections between drug use and the perspectives of public health were limited. Drugs like opium were freely available until the late 1860s, when qualified pharmacists were required to dispense such medication; however, opium did somewhat enter into the public health movement in the 1840s, with investigation of claims that the industrial working classes were using opiates rather than alcohol (13). This demonstrates the fear of the urban mass that lay behind the environmentalism of public health at that time. 
Inebriety, the term used to describe a disease of alcohol or opium consumption, spread not through infection but rather through heredity. The Society for the Study of Inebriety, the main medicopolitical organization concerned with disease at the time, and containing Medical Officers of Health among its membership, focused on securing a network of publicly funded inebriate asylums. These asylums were to be locations in which inebriates were committed compulsorily. This was similar to insanity legislation, but performed in the name of public health. The public health strategy of notification was also institutionalized at this time through the 1889 Notification of Infectious Disease Act.

By World War I, these elements of public health were weaker, and the term inebriety was replaced by addiction. Sir William Collins, the new President of the Society for the Study of Inebriety, described addiction as 'a disease of the will' (14). This signalled a change in focus in the 1920s to the addict's neurosis, a decline of the institutional option, and the rise of psychological imperatives within insanity. The addict's profile was a middle class one. The Canadian historian Samuel Shortt (15) pointed out that these new theories enabled alienists (psychiatrists) to expand their professional options beyond the confines of the asylum to a middle class clientele.

\section{PUBLIC HEALTH AND DRUGS IN THE 1960s}

Drugs and public health were driven further apart after the 1920s, with treatment and maintenance being the primary responses for the next 40 years. Additionally, the 1960s saw a rapid rise in the number of drug users and drugs available to the public. This expanding drug use resulted in two separate enquiries chaired by Sir Russell (later Lord) Brain. This enquiry found that the number of heroin addicts rose from 68 to 342 in total from the late 1950s to the mid-1960s. Cocaine use also increased during this period, and as the recreational use of illicit drugs increased, users began to develop addiction at a younger age. Amphetamines and cannabis were also reported to be heavily used.

The Brain Committee released a second report in 1965 that provided a basis for subsequent power relationships within drug policy and the development of new ideas of health care and public health. The proposal took the prescribing of heroin and cocaine out of the hands of general practitioners and made it the task of specialist hospital doctors or psychiatrists. This enactment allowed general practitioners to continue to prescribe dangerous drugs to ordinary patients (ie, for pain relief in acute or chronic disease treatment) but imposed restrictions on prescribing heroin and cocaine to addicts. The committee made three linked proposals: a restriction to the supply of heroin and cocaine to licensed doctors; the development of treatment centres for addicts; and a system of notification of drug addicts, to the Home Office, the justice ministry. This mixed medical views of addiction with both a criminal justice and public health rationale. The model of drug addiction became one of 'outbreak control':

"We think the analogy to addiction is apt, for addiction is after all a socially infectious condition and its notification may offer a means for epidemiological assessment and control. We use the term deliberately to reflect certain principles which we regard as important, viz that the addict is a sick person and that addiction is a disease which (if allowed to spread unchecked) will become a menace to the community" (16).
In the 1980s, the threat of HIV spreading in the general population justified a response designed to minimize harm from drug use. This included attracting drug users into the health care system through substitute prescribing or the provision of sterile equipment. Gerry Stimson, a leading United Kingdom drug researcher made the following point:

"HIV has simplified the debate and we now see the emergence of what I will call the public health paradigm. Rather than seeing drug use as a metaphorical disease, there is now a real medical problem associated with injecting drugs. All can agree that this is a major public health problem for people who inject drugs, their sexual partners and their children" (17).

The public health issue was, in fact, wider than this; there was the danger of the spreading of infection into the general population. The language of 19th century public health and the spread of epidemic disease informed these public health moves, and were behind moves to revive public health more generally in the wake of AIDS. Sir Donald Acheson, the Chief Medical Officer in Britain, produced a report in 1988 notable for its references to AIDS and 19th century history. AIDS, it argued, would lead to a revival of traditional infection control in public health (18).

\section{AIDS, ILLICIT DRUGS AND PUBLIC HEALTH}

The model of public health adopted in the 19th century was revived in the 20th century in the quest to curb the spread of infectious disease. Infection control, both in relation to drugs and in public health more generally, was back in the forefront of public health. Hepatitis C, for example, is a growing issue of concern for drug policy. The issue of infectious disease is also more prominent in public health in general; for example, with bovine spongiform encephalopathy, and foot and mouth disease.

It is tempting to conclude that public health policy is returning to its 19th century heroic environmental period and drugs are a part of that tendency. However, the situation is far more complex than that. Tensions have always existed both within public health and within drug policy, by virtue of the mixed emphases on community versus individual and medical versus penal approaches. Medical approaches also can be oriented toward the individual and treatment, or guided by a general population aim.

In the early 21st century, two variations of the new public health approaches to drugs are emerging. The earlier lifestyle image of public health and drug use that focused on the drug user as a normal individual and on individual choice is seceding to new versions of public health intervention. The first version looks at the individual within the environment rather than at the environment in a broader context; this is the new environmental approach. In Britain, the idea of community safety pervades official documents. The concept intends to make the environment safe for the nondrug and nonalcohol consuming community. The recent proposal for safe injection sites takes this a step further by providing a safe environment where drugs can be taken. These approaches mingle environmental, individual and criminal justice interventions.

Variant number two focuses on treatment as prevention. As seen in the 19th century, this intervention focuses on medical input rather than the 'traditional public health approach'. Technical issues such as methadone maintenance and possible 
heroin prescription are seen not only as treatments, but as public health strategies. They are a means of prevention or reducing harm; this may be termed 'pharmaceutical public health'. Similar tendencies are seen in other public health areas; for example, the use of nicotine replacement therapy as a public health strategy for smoking, and the focus on vaccine development internationally.

\section{CONCLUSIONS}

History is not a predictive discipline, and how these models develop in the future cannot be foretold. However, the relationship between drugs and public health shows how changing responses in both fields are intersecting. This reflects developments that have taken place within the field of drug policy and

\section{REFERENCES}

1. de Tocqueville A. Journeys to England and Ireland. London: Faber and Faber, 1958:107-8.

2. Chadwick E. Report on the sanitary condition of the labouring population of Great Britain. London: Routledge/Thoemmes Press, 1997.

3. Hamlin C. Public Health and Social Justice in the Age of Chadwick: Britain 1800-1854. Cambridge: Cambridge University Press, 1998.

4. Worboys M. Spreading Germs: Disease Theories and Medical Practice in Britain, 1865-1900. Cambridge: Cambridge University Press, 2000.

5. Porter D. Health Civilization and the State: A History of Public Health from Ancient to Modern Times. London: Routledge, 1999.

6. Lewis J. The Politics of Motherhood: Child and Maternal Welfare in England, 1900-1939. London: Croom Helm, 1980.

7. Ministry of Health. A National Health Service. London: HMSO, 1944.

8. Webster C. The NHS: A Political History. Oxford: Oxford University Press, 1998.

9. Lalonde M. A New Perspective on the Health of Canadians. $<$ http://www.hc-sc.gc.ca/hppb/phdd/pdf/perspective.pdf> (Version current at May 11, 2005).

10. McKeown T. The modern rise of population. London: Edward Arnold, 1976. direct us in our thoughts and applications of public health today. Knowledge of the past may help us in the development of appropriate future strategies. The public health approaches we take today will play a role in public health endeavours throughout the 21st century and beyond.

ACKNOWLEDGEMENTS: The authors wish to acknowledge and thank Dr Morris Goldner, Professeur associé de biologie médicale, Faculté de médécine, Université Laval and President of the Stanier Institute for his assistance in preparing materials for the preparation of the present report. The authors would also like to thank Dr Goldner and Dr Gregory Horsman, Medical Director, Provincial Laboratory Saskatchewan Health, for their assistance in reviewing and providing technical oversight in the production of the present report.

11. Wanless D. Securing Good Health for the Whole Population. Final Report Chapter Two. <http://www.hm-treasury.gov.uk/ consultations_and_legislation/wanless/consult_wanless04_final.cfm> (Version current at April 1, 2005).

12. Berridge $\mathrm{V}$. Post-war smoking policy in the UK and the redefinition of public health. 20 Century Br Hist 2003;14:61-82.

13. Berridge V. Opium and the People: Opiate use and drug control policy in nineteenth and early twentieth century England. Expanded 2nd ed. London: Free Association Books, 1999.

14. Collins Sir W. The ethics and law of drug and alcohol addiction. British J Inebriety 1916;13:131-54.

15. Shortt SED. Victorian Lunacy: Richard M Bucke and the Practice of Late Nineteenth Century Psychiatry. Cambridge: Cambridge University Press, 1986.

16. Interdepartmental Committee on Drug Addiction (1965). The Brain Committee Report. London: HMSO: 8.

17. Stimson G. Reviewing policy and practice: New ideas about the drugs problem. In: Strang J, Stimson G, eds. AIDS and Drug Misuse. London: Routledge, 1990.

18. Berridge V. AIDS in the UK: The Making of Policy 1981-1994. Oxford: Oxford University Press, 1996. 


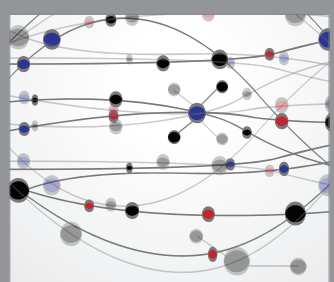

The Scientific World Journal
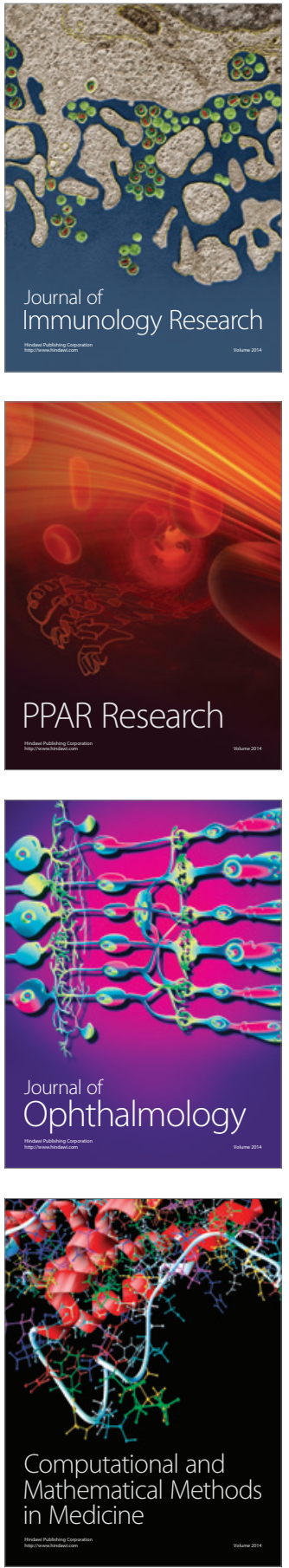

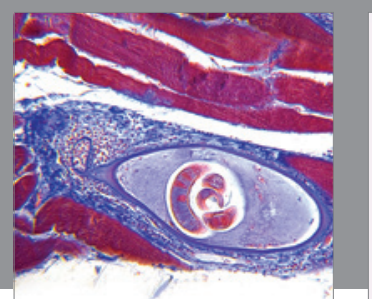

Gastroenterology Research and Practice

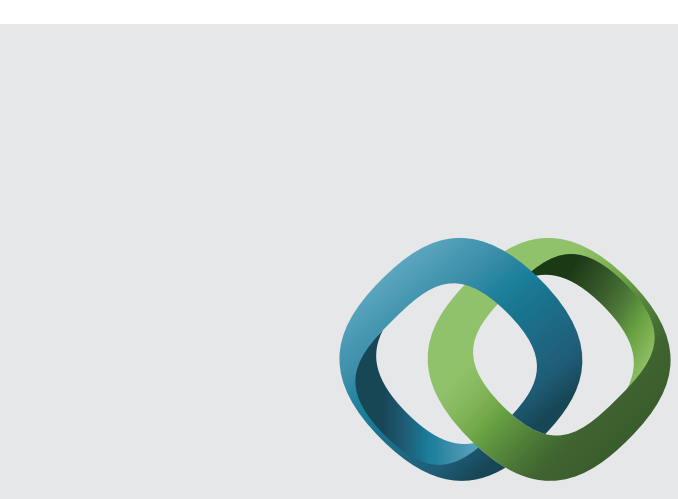

\section{Hindawi}

Submit your manuscripts at

http://www.hindawi.com
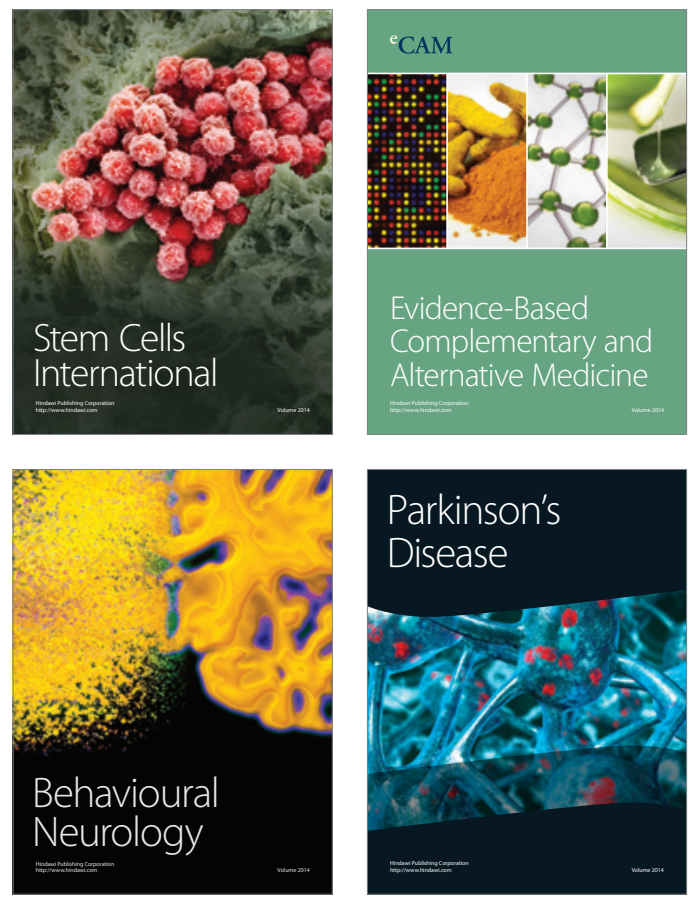
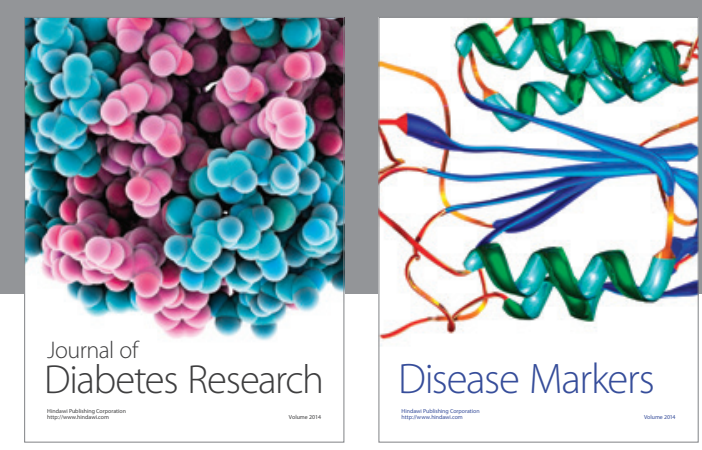

Disease Markers
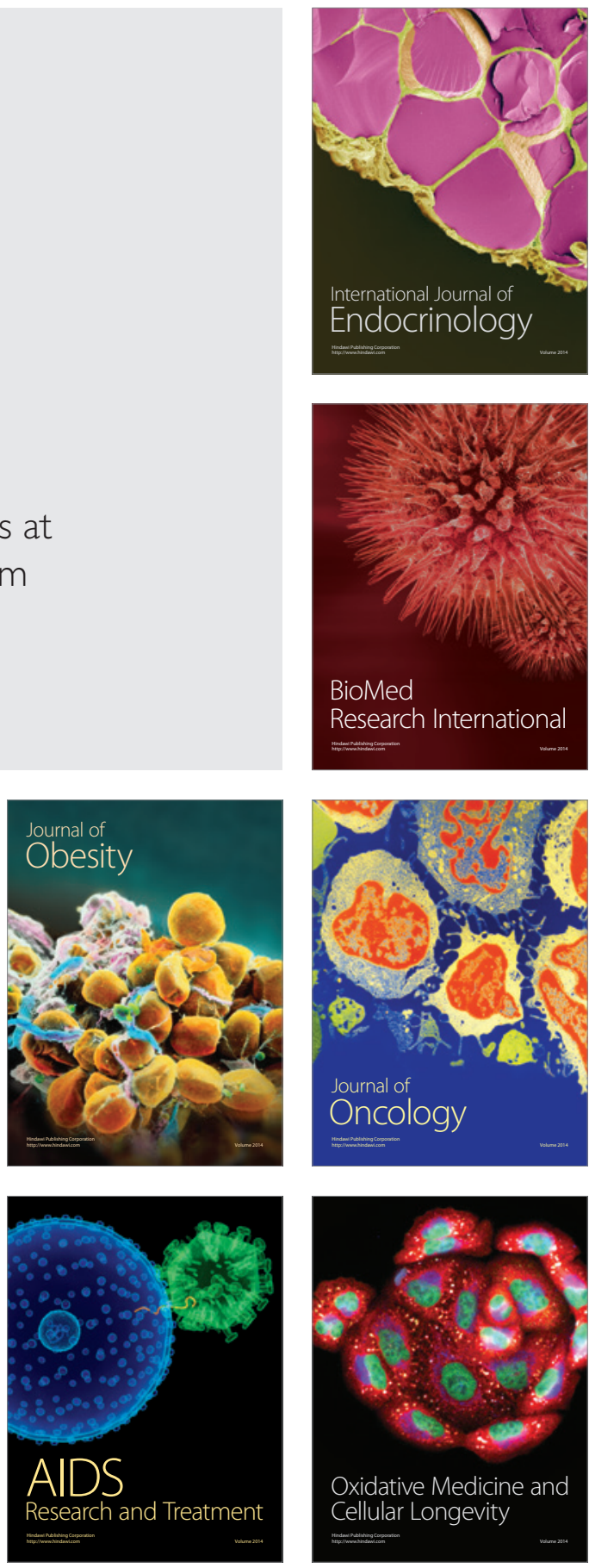